\title{
703 自由界面を有する矩形容器内自然対流の伝熱現象と赤外線計測
}

\author{
Heat Transfer Phenomenon of Natural Convection in an Open Vessel \\ and Its Infrared Sensing
}

伝正稲垣照美(茨城大) $\bigcirc$ 羽鳥雅一(茨城大院) 伝正 椎名保顕(原研大洗)

\author{
Terumi INAGAKI ${ }^{1}$, Masakazu HATORI ${ }^{1}$, Yasuaki SHIINA ${ }^{2}$ \\ ${ }^{1}$ Ibaraki University, 12-1 Nakanarusawa 4 Chome, Hitachi, Ibaraki, 316-8511, Japan \\ ${ }^{2}$ JAERI, 3607 Narita-Cho, Oarai-Machi, Higashi Ibaraki-Gun, Ibaraki, 311-1394, Japan
}

As infrared thermography has a convenient feature that we can diagnose two-dimensional temperature fields nondestructively and simultaneously at every picture element, it has widely been applied to various engineering applications. Therefore, in this paper, the surface temperature field having free surface was visualized and measured by sensing infrared energy emitted from the liquid-gas interface directly as electromagnetic waves. The heat transfer phenomena were also discussed by analyzing the temperature data statistically. Another aim is to confirm the applicability of infrared thermography to quantitative heat transfer measurement for a liquid-gas interface.

Key Words: Infrared Thermography, Thermal Visualization, Liquid-gas Interface, Heat Transfer.

\section{1. 緒合}

赤外線サーモグラフィーは、対象物から発せられる熱エネ ルギーを感知し、その表面温度を非破壊りモートセンシング に評価する手段であるとともに、複雑な形状を有する二次元 温度場をリアルタイムにかつ画素毎に診断・評価することが 可能な手段でもある。伝熱学の分野においては、これまで主 に加熱固体壁面の温度計測あるいは伝熱計測(1)に利用されて 来たが、気液界面現象への定量的な適用性や有効性について は、十分な知見が得られていない。気液界面の計測では、界 面自体にセンサを直接接触させなければならず、伝熱計測が 難しいと喜える。

このことから、本研究では、気液界面伝熱現象の代表例と して片面に自由界面を有する有限矩形容器内のべナールセル 対流を取り上げ、気液界面温度場の可視化や計測に赤外線サ 一モグラウィーを応用することにした。また、気液界面の定 量的な対流伝熱計測も試みることにした。気液界面伝熱現象 を解明する上では、赤外線サーモグラフィーのような非接触 な計測が望ましい。

\section{2. 実臨装量及び計测方法}

計測は、赤外線サーモグラフィー装粗（NEC SANEI 製 TH3100MR、スターリング冷却方式、 Hg-Cd-Te センサ、検出 波長域 8-13 $\mu \mathrm{m}$ 、温度測定範团-50 2000 ${ }^{\circ} \mathrm{C}$ 、画像生成時間 $0.75 \mathrm{~s}$ 、最小検知温度分解能 $0.1^{\circ} \mathrm{C}$ ) を使用し、任意の水平走查 ライン（あるいはポイント）上の温度を時系列でサンプルす るタイムトレースモードを適用した。一つの熱画像は、239 本の水平走査ラインで構成され、ある 1 つの水平ラインを走 查して次の走查までに $3.125 \mathrm{~ms}$ を要する。なお、この走查時 間 $3.125 \mathrm{~ms}$ の中には、CRT 表示時間 $1.25 \mathrm{~ms}$ が含まれている。 従って、1 画像生成時間は、 $3.125 \mathrm{~ms} \times 239$ 本 $\div 0.75 \mathrm{~s}$ となる。

図 1 は、実験装置の概略を示したものである。伝熱面は、

上から銅板（厚さ $1 \mathrm{~mm}$ ) そして熱源であるステンレス簿（幅 $10 \mathrm{~mm}$ の短冊状に加工、厚さ $30 \mu \mathrm{m})$ の順に張り合わせ、周 囲を充分に断熱した厚さ $10 \mathrm{~mm}$ の水平なアクリル矩形容器

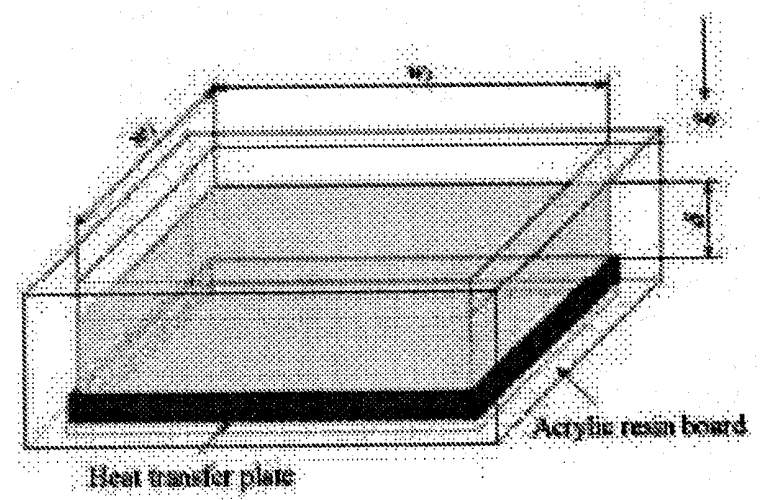

Fig.1 Experimental Apparatus

（濡れ縁底面積 $w_{1} \times w_{2}\left[\mathrm{~mm}^{2}\right]$ ) の底面に固定した。ここで、実 験では、 $w_{1} \times w_{2}=100 \times 100$ (Model I)、100×200 (Model II) および $100 \times 300$ (Model III) のアスペクト比が異なるアクリ ル矩形容器を用いた。但し、矩形容器の高さは $20 \mathrm{~mm}$ で同一 である。ここでは、銅板を用いることにより伝熱面温度を一 定にした。伝熱面（加熱面）温度の計測は、予め検定した直 径 $100 \mu \mathrm{m}$ のC-A 熱電対を銅箔の裏面に 5 カ所スポット溶接 して行った。また、実験装置のアクリル矩形容器底部からの 漏洩熱量を計測するため、熱流束センサ (ゼネレクス製 BF-04 型、 $\left.25 \times 25\left[\mathrm{~mm}^{2}\right]\right)$ を貼り付けて正味熱流束を補正した。

実験は、暗室内に赤外線サーモグラフィー装固の検出部と 実験装置を同時に設置し、気液界面温度計測を検出部から $0.45 \mathrm{~m}$ の距離で実施した。実験装睓には、作動流体としてシ リコンオイルを充填してある。シリコンオイルは動粘度 $\boldsymbol{\nu か ゙ ~}$ $50,100,300,500 \mathrm{cst} の 4$ 種類を用意し、流体層深さ $\delta$ は 5,10 , $15 \mathrm{~mm}$ と変化させ、それぞれの条件につき加熱面温度が約 $80^{\circ} \mathrm{C}$ になるで徐々にジュール加熱した。なお、暗室内温度 は、直径 $300 \mu \mathrm{m}$ の C-A 熱電対を検出部と装置の中間付近に 2 力所取り付けて計測した。 


\section{3. 結果及び考察}

\section{1. 気液界面の可梘化}

Fig.2 は、 $\nu=500 \mathrm{cst}, \delta=10 \mathrm{~mm}$ における気液界面温度場を、 赤外線サーモグラフィーにより可視化した結果の一例を示し たものである。図中 $\boldsymbol{R a}_{l}$ は、流体層側のレイリ数である。Fig.2 の(a)、(e)から、加熱量が小さければセルが発生せず、一様な 温度分布になっていることが分かる。また、Fig.2 の(b)、(c) 及び(e)、(f)から、加熱量が増加し、臨界レイリ数を超えると 筋上の対流が発生した後、ベナールセルが形成される。なお、 流体力学ハンドブック (2)より求められるべナールセル発生臨 界レイリ数は、これらの条件に対して(a)〜 (c)が 1124、(d)〜 (f) が 1113 である。また、Fig.3は、Model I における可視化結 果と数值計算結果を比較したものである。 $R a_{l}=1.05 \times 10^{4}$ に対 しては、いずれの場合も容器内に 49 個のセルが出現している ことがわかる。なお計算は、可視化実験と同一の条件下で行 ない、コントロールボリューム法により定常三次元の支配方 程式を解いた結果である。なお、式中の浮力項には、ブジネ スク近似を施した。

\section{2. 対流伝熱計測}

Fig.4 は、ベナールセル発生前から乱流遷移にいたるまでの $\nu=500 \mathrm{cst}$ における気液界面の気相側平均ヌセルト数 $N u$ を、 気相側修正レイリ数 $\boldsymbol{R a}_{\boldsymbol{g}}^{*}$ に対して示したものである。また、 線群は、熱流束一定条件下の垂直加熱平板における層流自然 対流 (3),(4)、及び熱流束一定条件下の水平加熱平板における自 然対流(5)の平均ヌセルト数 $\mathrm{Nu}$ である。気液界面における平均 ヌセルト数は、固体壁面のものと比べて Model I 、Model II、 Model III ともに大きな違いは見られなかった。したがって、 修正レイリ数の小さな極低流速の自然対流では、界面におけ る摩擦の影響が少ないものと推察できる。

\section{4. 結言}

本研究は、赤外線サーモグラフィーを利用して気液界面の 伝熱現象を可視化および計測したものである。非接触な赤外 線サーモグラフィーは、ベナールセル対流表面の温度場を可 視化する上で有効な手法であることが確認された。また、気 液界面の定量的な対流伝熱計測の可能性について検証するこ とができた。今後は、対流伝熱計測についてさらに研究を進 める予定である。

\section{絫考文献}

(1) T.Inagaki and Y.Okamoto, Measurement of Turbulent Heat Transfer Coefficients Using Infrared Thermography near Ambient Conditions and Its Quantitative Error Estimation, J.of JSME International, Series B, Vol.42 (1999), 275.

（2）日本流体力学会編，流体力学ハンドブック 第 2 版, (1998), 292.

(3) Vliet 他 1 名, Journal of Heat Transfer, 91 (1969), 517

(4) 甲藤, 伝熱概論, (1996), 88 .

（5）北村他 1 名, 機論, 58-556, B(1992), 3715.

\section{記号表}

$\overline{\boldsymbol{h}}:$ 空気側平均熱伝達率 $\left[=\boldsymbol{q}_{\text {conv }} /\left(\boldsymbol{T}_{\boldsymbol{s}}-\boldsymbol{T}_{\boldsymbol{\infty}}\right)\right]$

$L$ : 代表長さ [等価直径 $=4 w_{1} w_{2} / 2\left(w_{1}+w_{2}\right)$ ]

$\mathrm{Nu}:$ 空気側ヌセルト数 $[=\bar{h} L / 2]$

$q_{c o n v}$ : 空気側対流熱流束 $\left[=q_{i n}-q_{\text {rad }}-q_{\text {loss }}\right]$

$R a^{*}$ : 空気側修正レイリ数 $\left[=g \beta q_{c o n v} L^{4} \operatorname{Pr}_{g} / \lambda \nu^{2}\right]$

$R a_{l}$ : 流体層側レイリ数 $\left[=g \beta\left(T_{w}-T_{\infty}\right) \delta^{3} P_{l} / \nu^{2}\right]$

$q_{\text {loss }}$ : 漏洩熱流束、 $\boldsymbol{q}_{\text {in }}$ : 流入熱流束、 $\boldsymbol{q}_{\mathrm{rad}}$ : $<<$ 射熱流束

$T_{w}$ : 加熱面温度、 $T_{s}$ : 気液界面温度、 $T_{\infty}$ : 周囲大気温度 $w_{1}:$ 横内寸法、 $w_{2}$ : 繸内寸法
Model I

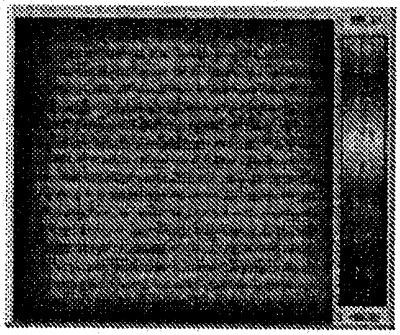

(a) $R a_{l}=3.68 \times 10^{2}$

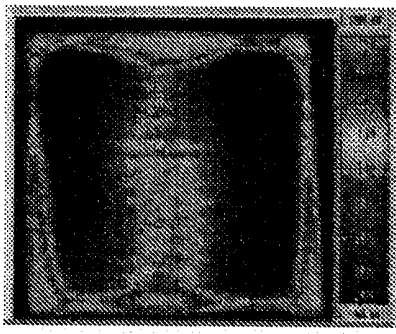

(b) $R a_{l}=1.57 \times 10^{3}$

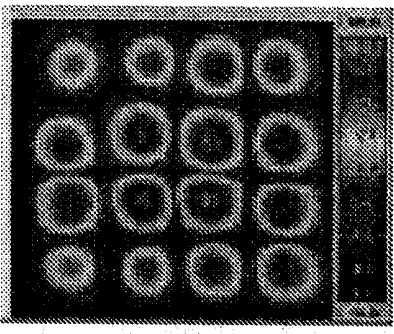

(c) $R a_{\Gamma}=8.54 \times 10^{3}$
Model III

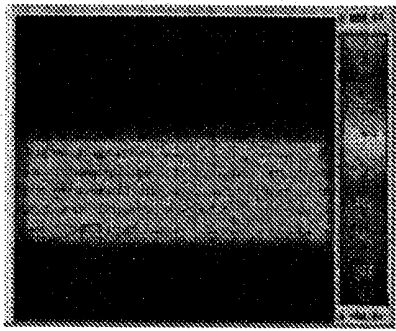

(d) $R a_{\digamma}=3.7 \times 10^{2}$

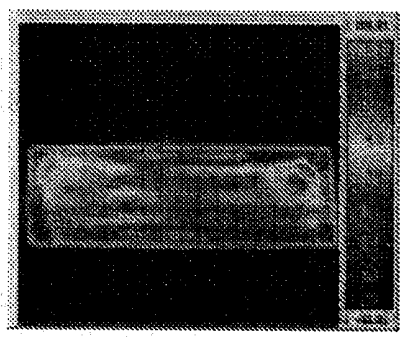

(e) $R a_{i}=1.68 \times 10^{3}$

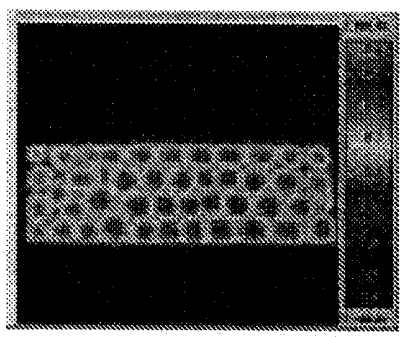

(f) $R a_{l}=4.72 \times 10^{3}$
Fig.2 Visualized Thermal Patterns ( $\nu=500 \mathrm{cst}, \delta=10 \mathrm{~mm}$ )

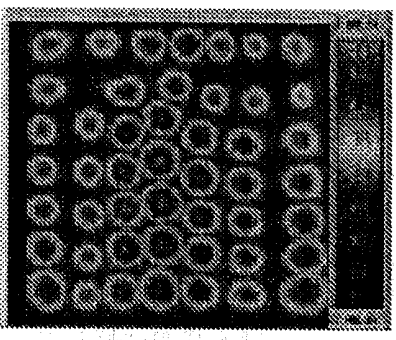

(a) Visualized Thermal Pattern

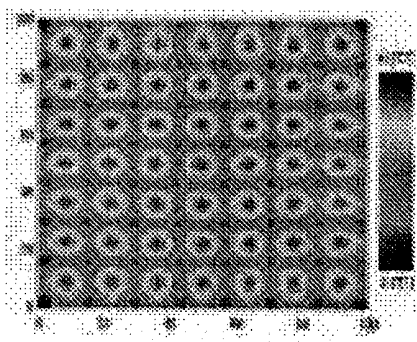

(b) Simulated Thermal Pattern
Fig. 3 Numerical Calculation ( $\nu=50 \mathrm{cst}, \delta=10 \mathrm{~mm}, R a_{l}=1.05 \times 10^{4}$ )

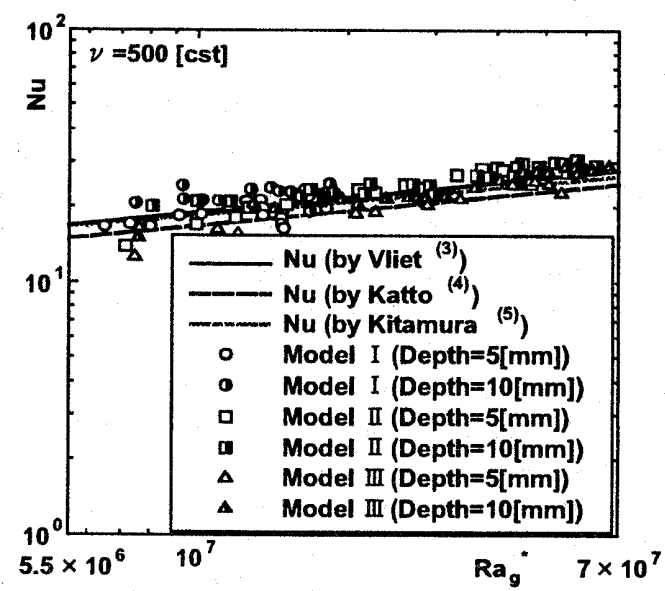

Fig.4 Nusselt Number at Liquid-gas Interface 